\title{
Functional and Physical Interaction between p53 and BZLF1: Implications for Epstein-Barr Virus Latency
}

\author{
QIN ZHANG, DAVID GUTSCH, AND SHANNON KENNEY* \\ Department of Medicine and Lineberger Comprehensive Cancer Research Center, University of \\ North Carolina at Chapel Hill, Chapel Hill, North Carolina, 27599
}

Received 14 May 1993/Returned for modification 9 July 1993/Accepted 10 December 1993

\begin{abstract}
The p53 tumor suppressor protein, which is commonly mutated in human cancers, has been shown to interact directly with virally encoded proteins from papillomavirus, adenovirus, and simian virus 40 . The disruption of p53 function may be required for efficient replication of certain viruses and may also play a role in the development of virally induced malignancies. Infection with Epstein-Barr virus (EBV) has been associated with the development of B-cell lymphomas and nasopharyngeal carcinoma. Here we show that the EBV immediate-early protein, BZLF1 (Z), which is responsible for initiating the switch from latent to lytic infection, can interact directly in vitro and in vivo with the tumor suppressor protein, $p 53$. This interaction requires the coiled-coil dimerization domain of the $Z$ protein and the carboxy-terminal portion of p53. Overexpression of wild-type p53 inhibits the ability of $Z$ to disrupt viral latency. Likewise, $Z$ inhibits p53-dependent transactivation in lymphoid cells. The direct interaction between $Z$ and p53 may play a role in regulating the switch from latent to lytic viral infection.
\end{abstract}

The p53 tumor suppressor protein is an important negative regulator of cell proliferation $(38,48,63,65)$ and is often mutated in human cancers $(26)$. The $\mathrm{p} 53$ protein interacts with the viral E6 protein from certain cancer-associated strains of human papillomavirus $(36,54,68)$, the E1b protein of adenovirus $(53,72)$, and the large $\mathrm{T}$ antigen of papovaviruses $(35$, 53). The dysregulation of wild-type p53 function by viral proteins is thought to play an important role in virus-induced malignancy (37).

The interaction between viral proteins and p53 may also play a role in the replication of certain viruses. The $\mathrm{p} 53$ protein binds to the simian virus 40 origin of replication (3) and inhibits the ability of large $\mathrm{T}$ antigen to mediate simian virus 40 replication in vitro $(19,67)$. In addition, p53 colocalizes with the viral replication proteins in cells infected with herpes simplex virus (70). These data suggest that p53 could potentially regulate the replication of herpesviruses through direct interaction with viral replicative proteins.

In this study, we have examined the ability of p53 to interact with the Epstein-Barr virus (EBV) protein BZLF1 $(Z)$, which mediates lytic replication. EBV is a transforming virus in vitro, and infection with EBV has been associated with the development of both B-cell and epithelial cell malignancies in vivo (reviewed in reference 44). EBV infection of B cells in vivo is primarily latent, although productive infection can occur in immunocompromised patients. The switch from latent to productive infection is mediated by transcriptional activation of the immediate-early $Z$ gene $(6,52,62)$. The $Z$ gene product (a member of the basic leucine zipper family) binds directly to AP1-like motifs as a homodimer and functions as a transcriptional transactivator $(5,12,14,30,34,39,49,64)$. A number of viral early promoters contain upstream Z-binding sites and are activated upon expression of the $Z$ gene product $(6,8,12,14$, $25,29,49,64)$. The $Z$ protein also binds directly to the EBV lytic origin of replication (ori-Lyt) and is required for lytic replication $(13,55)$.

In this report, we demonstrate that $\mathrm{Z}$ can interact directly

\footnotetext{
* Corresponding author.
}

with the p53 protein in vitro as well as in vivo. We show that wild-type p53 inhibits the ability of $Z$ to mediate the switch from latent to productive viral infection. Therefore, the presence of wild-type $\mathrm{p} 53$ protein in cells may tend to promote viral latency.

\section{MATERIALS AND METHODS}

Cell lines. The cell lines used include the EBV-negative Burkitt's lymphoma B-cell line Louckes, the latently infected EBV-positive Burkitt's lymphoma B-cell lines Raji and Akata, the cervical epithelial cell line HeLa (papillomavirus positive), the primary human fibroblast cell line IMR-90, and the D98/ HE-R-1 cell line, which was formed by fusion of a HeLa cell subclone (D98) with the EBV-positive Burkitt's lymphoma cell line P3HR-1 (45). In addition, we used clonal cell lines derived from either Akata cells stably transfected with a construct containing wild-type p53 under the control of the inducible metallothionein promoter or clones stably transfected with the pMEP4 vector (Invitrogen) alone. The stably transfected Akata cell lines (gifts from Paul Farrell) have been previously described (66). All lymphoid cell lines were maintained in RPMI 1640 medium supplemented with $10 \%$ fetal calf serum. All epithelial and fibroblast cell lines were maintained in Dulbecco modified Eagle medium $\mathrm{H}$ supplemented with $10 \%$ fetal calf serum.

Plasmids. (i) EBV transactivator plasmids. Construction of the BRLF1 ( $R$ ) and $Z$ transactivating plasmids has been previously described $(25,30,49)$. The $Z$ plasmid (pCMV-Z) (30) contains the EBV Z cDNA (a gift from Alain Sergeant) cloned into the pGEM2-based vector pHD1013 such that the Z immediate-early gene is under the control of the strong cytomegalovirus immediate-early (CMV IE) promoter. The R plasmid (pEBV-RIE) contains the $R$ immediate-early gene (contained within a genomic EBV fragment) linked to the CMV IE promoter in a pUC-based plasmid $(25,49)$.

(ii) EBV promoter plasmids. The BMRF1-CAT construct (formerly referred to as EA-BS-CAT) has been previously described (25) and contains the early EBV promoter BMRF1 sequences from -331 to +1 (relative to the RNA start site) 
linked to the chloramphenicol acetyltransferase (CAT) gene in the Bluescript SK + phagemid vector (Stratagene). The BHRF1-CAT construct contains the early EBV BHRF1 promoter sequences (from -972 to +46 relative to the RNA start site) linked to the CAT gene in the pBS-CAT vector (a gift from Frank Funari).

(iii) Bacterial $\mathbf{Z}$ proteins. The glutathione $S$-transferase (GST) $-Z$ fusion protein contains the entire $Z$ open reading frame inserted in frame into the $\mathrm{pGEX}-3 X$ vector (Pharmacia) downstream of the GST protein. Three deletions of GST-Z, removing either amino acids 25 to 86 (in frame) from the transactivator domain ( $\mathrm{Z} \Delta 25-86)$, amino acids 200 to 227 (in frame) from the coiled-coil dimerization domain ( $\mathrm{Z} \Delta 200-227)$, or amino acids 0 to 143 (in frame), were also constructed.

(iv) p53 plasmid constructs. The p53 reporter construct, pG13-CAT (a gift from Bert Vogelstein), has been previously described (32) and contains 13 copies of the consensus p53 binding site upstream of the polyomavirus early promoter linked to the CAT gene (32). The p53 transactivator plasmids, pC53-SN3, pC53-SCX3, pC53-175, and pC53-248 (gifts from Bert Vogelstein), have been previously described (2) and contain either wild-type (pC53-SN3) p53 or p53 mutated at amino acid 143 (pC53-SCX3), 175 (pC53-175), or 248 (pC53248) under the control of the CMV IE promoter. In addition, the BamHI fragments (containing the p53 gene) of these constructs were recloned into the pBS vector (Stratagene) downstream of the $\mathrm{T} 7$ promoter. By using these new constructs, in vitro-translated wild-type (or mutant) p53 was obtained by in vitro transcription with $\mathrm{T} 7$ polymerase, followed by in vitro translation (in the presence of $\left[{ }^{35} \mathrm{~S}\right]$ methionine) with reticulocyte lysate (Promega). The mutant p53 proteins, p53 $\Delta 375$ and p 53 $\Delta 345$, were obtained by cutting the wild-type p53 pBS construct with either AccI or SmaI prior to in vitro transcription and translation.

DNA transfections. Plasmid DNA was purified through two sequential cesium chloride gradients. DNA was transfected into both lymphoid and epithelial cells by electroporation, using $10 \mu \mathrm{g}$ of DNA and $10^{7}$ cells per condition. Cells were shocked at $1,500 \mathrm{~V}$ with a Zapper electroporation unit (Medical Electronics Shop, University of Wisconsin). Epithelial cells were harvested and suspended in RPMI 1640 medium prior to electroporation.

CAT assays. Cell extracts were prepared $48 \mathrm{~h}$ after transfection and incubated at $37^{\circ} \mathrm{C}$ with $\left[{ }^{14} \mathrm{C}\right]$ chloramphenicol in the presence of acetyl coenzyme A as described previously (21). The percent acetylation of chloramphenicol was quantitated by thin-layer chromatography followed by scintillation counting or scanning with an AMBIS scanning densitometer (AMBIS, Inc.).

Analysis of EBV termini. To distinguish latent versus productive EBV infection, Southern blot analysis was used to determine the state of the EBV termini (fused versus unfused). Total cellular DNA was analyzed 3 days after transfection with the $\mathrm{Z}$ transactivator plasmid by cutting with the enzyme $B a m \mathrm{HI}$ and probing with a ${ }^{32} \mathrm{P}$-labeled riboprobe spanning the EBV sequences in the 1.9-kb XhoI fragment. As previously described (50), this probe can be used to determine the relative amount of EBV DNA containing fused versus unfused viral termini. Unfused termini are observed only in the linear form of the virus and are diagnostic of lytic infection.

Coimmunoprecipitation and Western blot (immunoblot) analysis. Transfected $\mathrm{Z}$ and $\mathrm{p} 53$ proteins in CAT assays were quantitated by Western blot analysis using monoclonal antibodies directed against either the $\mathrm{Z}$ protein (antibody BZ.1 [73], a gift from Alan Rickinson, directed against the dimerization domain of Z) or the p53 protein (antibody DO-1 [Santa
Cruz Biotechnology], directed against the amino-terminal portion of p53). Analysis of BMRF1 induction in Akata cells was done with monoclonal antibody 9240 (NEN/Dupont). Western blot analysis was performed in phosphate-buffered saline (PBS) with 5\% powdered milk, using a 1:10 dilution of monoclonal antibody BZ.1 or a 1:100 dilution of antibody DO-1, followed by washing three times at room temperature with $3 \%$ powdered milk-PBS and then addition of the secondary antibody (1:2,000 dilution of goat anti-mouse kappa-chain horseradish peroxidase-conjugated serum (Southern Biotechnology Associates)). In certain experiments (Fig. 1D), pooled sera from patients with nasopharyngeal carcinoma was used to detect transfected $\mathrm{Z}$ protein. In some cases (Fig. 6B), Western blotting was done with antibody DO- 1 which had been directly conjugated to horseradish peroxidase (to avoid cross-reaction of the anti-mouse secondary antibody with the mouse monoclonal antibodies used in the immunoprecipitations). Immunoblotting was done by using enhanced chemiluminescence performed as recommended by the manufacturer (Amersham Life Sciences).

Coimmunoprecipitation experiments were performed 2 days after transfection of D98/HE-R-1 cells with the $\mathrm{Z}$ or p53 expression vector or 1 day after anti-immunoglobulin $\mathrm{G}(\mathrm{IgG})-$ cadmium chloride treatment of the Akata cell subclones. Cells were rinsed with cold PBS, pelleted, frozen in dry ice, thawed, and resuspended in $0.4 \mathrm{ml}$ of buffer $(50 \mathrm{mM}$ Tris- $150 \mathrm{mM}$ $\mathrm{NaCl}-0.5 \mathrm{mM}$ EDTA-0.5\% Nonidet $\mathrm{P}-40$ [pH 8.0] supplemented with $1 \mathrm{mM}$ phenylmethylsulfonyl fluoride and $1 \mu \mathrm{M}$ pepstatin [Boehringer Mannheim] protease inhibitors). The cell lysate was then sonicated six times and pelleted again, and equal amounts of protein supernatant (approximately $100 \mu \mathrm{g}$ ) were incubated overnight at $4^{\circ} \mathrm{C}$ with $10 \mu \mathrm{l}$ of either p53specific antibody DO-1, Z-specific antibody BZ.1, or c-Myc monoclonal antibody C-33 (Santa Cruz Biotechnology). Extracts were then immunoprecipitated with protein A-Sepharose 4B beads (Sigma) and washed five times (at $4^{\circ} \mathrm{C}$ ) in buffer containing $20 \mathrm{mM} \mathrm{N}$-2-hydroxyethylpiperazine- $N^{\prime}$-2-ethanesulfonic acid (HEPES; pH 7.7), $75 \mathrm{mM} \mathrm{KCl,} 0.1 \mathrm{mM}$ EDTA, $25 \mathrm{mM} \mathrm{MgCl}_{2}, 10 \mathrm{mM}$ dithiothreitol, and $0.15 \%$ Nonidet P-40. The immunoprecipitated proteins were separated on a sodium dodecyl sulfate (SDS)-8\% gel, transferred to nitrocellulose paper, and analyzed by Western blot analysis using either p53-specific antibody DO-1 or Z-specific antibody BZ.1 as described above.

GST fusion protein affinity chromatography. The ability of ${ }^{35} \mathrm{~S}$-labeled, in vitro-translated $\mathrm{p} 53$ proteins to interact with the various GST-Z fusion proteins was analyzed by affinity chromatography as previously described $(60,69)$. Bacterial cultures $(50 \mathrm{ml})$ containing either the pGEX-3X vector or the various GST-Z constructs were induced with isopropylthiogalactopyranoside (IPTG), pelleted, resuspended in $5 \mathrm{ml}$ of PBS, sonicated, and cleared of bacterial debris by centrifugation at $12,000 \times g$. For each condition, $100 \mu l$ of the lysate was incubated in $1 \mathrm{ml}$ of PBS for $20 \mathrm{~min}$ at room temperature with $5 \mu \mathrm{l}$ of glutathione-agarose beads (Sigma). The GST proteins were purified by three cycles of centrifugation and washing in 1-ml aliquots of buffer containing $20 \mathrm{mM}$ HEPES ( $\mathrm{pH} 7.7$ ), 75 $\mathrm{mM} \mathrm{KCl}, 0.1 \mathrm{mM}$ EDTA, $25 \mathrm{mM} \mathrm{MgCl}_{2}, 10 \mathrm{mM}$ dithiothreitol, and $0.15 \%$ Nonidet P-40. The purified GST protein was then incubated with $15 \mu \mathrm{l}$ of ${ }^{35} \mathrm{~S}$-labeled, in vitro-translated p53 protein in $1 \mathrm{ml}$ of the wash buffer for $1 \mathrm{~h}$ at room temperature. Bead complexes were washed five times in the buffer described above, centrifuged, resuspended in Laemmli sample buffer, and then analyzed by electrophoresis on SDS- $8 \%$ polyacrylamide gels followed by autoradiography. 
A

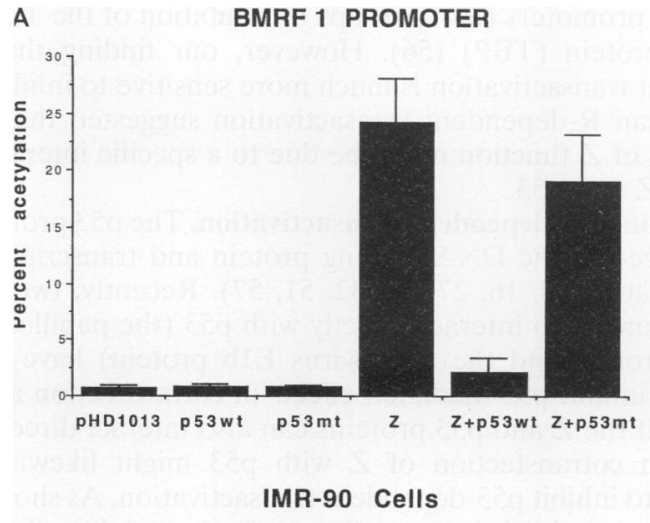

B
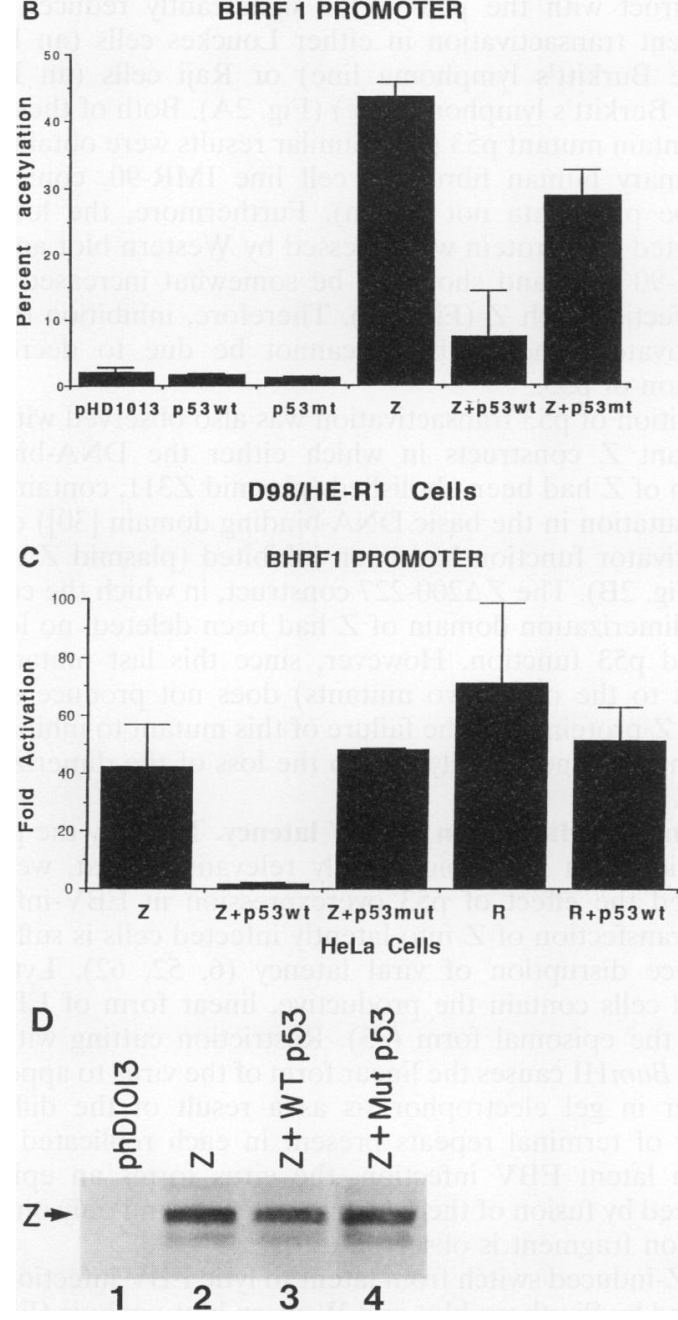

FIG. 1. Cotransfection of $p 53$ and $Z$ results in inhibition of $Z$ transactivator function. (A and $B$ ) The effects of $p 53$ upon $Z$-induced transactivation of the early BMRF1 promoter (A) or the early BHRF1 promoter (B) were examined in the IMR-90 cell line (a primary human fibroblast cell line containing wild-type p53) (A) or the D98/He-R-1 cell line (a fusion between HeLa cells and the EBV-positive Burkitt's lymphoma cell line P3HR1) (B). The percent acetylation of ${ }^{14} \mathrm{C}$ labeled chloramphenicol in each condition (measured as previously described [21]) is shown. Columns (left to right): $5 \mu \mathrm{g}$ of the promoter-CAT plasmid and $5 \mu \mathrm{g}$ of pHD 1013 vector DNA (containing the CMV IE promoter); $5 \mu \mathrm{g}$ of promoter-CAT plasmid, $5 \mu \mathrm{g}$ of $\mathrm{pHD} 1013$ vector, and $1 \mu \mathrm{g}$ of the p53 wild-type (p53wt) construct

\section{RESULTS}

p53 inhibits Z-dependent transactivation of early EBV promoters. Initial experiments examined the effect of p53 protein upon $\mathrm{Z}$ transactivator function in cotransfection assays. Two different early EBV promoters (linked to the reporter CAT gene) containing previously defined Z-binding sites were assayed for the ability to respond to the $\mathrm{Z}$ transactivator in the presence or absence of overexpressed p53 protein. Overexpression of wild-type p53 in transient assays significantly decreased the ability of $Z$ to activate the EBV early BMRF1 promoter $(25,49)$ (Fig. 1A) or the early BHRF1 promoter (8) (Fig. 1B). In contrast, p53 constructs containing mutations at amino acid 143, 175, or 248 had little or no effect (Fig. 1A to $\mathrm{C}$ and data not shown). The inhibitory effect of p53 upon $\mathrm{Z}$ transactivator function was observed in a variety of cell types, including HeLa and D98/HE-R-1 (both of which contain essentially no endogenous p53 because of the presence of the E6 papillomavirus protein, which degrades p53), Raji (which contains mutant p53 [11]), and primary human lung fibroblasts (IMR-90, which contain wild-type p53). The ability of the BHRF1 promoter to respond to another EBV immediate-early transactivator, $\mathrm{R}(8,22,24)$, was not significantly inhibited by p53 (Fig. 1C). The inhibitory effect of p53 upon $\mathrm{Z}$ transactivator function is unlikely to be an indirect result of p53 cell cycle effects, since cotransfection of the Rb tumor suppressor gene product (which produces similar effects upon the cell cycle) did not reduce $\mathrm{Z}$ transactivator function (data not shown). Furthermore, the levels of transfected $\mathrm{Z}$ protein (determined by Western blot analysis) in the same extracts used for determination of CAT activity were shown to be similar in the presence and absence of cotransfected p53 protein (Fig. 1D and 2C).

These data suggest that wild-type p53 protein inhibits Zinduced (but not R-induced) transactivation of early EBV promoters. The overexpression of p53 in cotransfection assays has been previously shown to inhibit the activity of a wide

(pC53-SN3) containing wild-type p53 cDNA under the control of the CMV IE promoter (2);5 $\mathrm{\mu g}$ of promoter-CAT construct, $5 \mu \mathrm{g}$ of pHD1013 vector, and $1 \mu \mathrm{g}$ of a p53 mutant $(\mathrm{p} 53 \mathrm{mt})$ construct (pC53-SCX3) mutated at amino acid 143 (2); $5 \mu \mathrm{g}$ of promoter-CAT construct and $5 \mu \mathrm{g}$ of the $\mathrm{Z}$ expression vector (pCMV-Z) containing the $\mathrm{Z}$ cDNA in the pHD1013 vector; $5 \mu \mathrm{g}$ of promoter-CAT plasmid, $5 \mu \mathrm{g}$ of pCMV-Z, and $1 \mu \mathrm{g}$ of wild-type p53 plasmid; $5 \mu \mathrm{g}$ of promoter-CAT plasmid, $5 \mu \mathrm{g}$ of pCMV-Z, and $1 \mu \mathrm{g}$ of mutant p53 construct. (C) The effects of wild-type versus mutant p53 upon transactivation of the early BHRF1 promoter by two different EBV immediate-early transactivators were compared in HeLa cells by using CAT assays (21). Fold transactivation of BHRF1 promoter activity is shown. Columns (left to right): $5 \mu \mathrm{g}$ of the $\mathrm{Z}$ transactivator construct, pCMV-Z, versus equal amounts of pHD1013 vector DNA; $5 \mu \mathrm{g}$ of pCMV-Z and $1 \mu \mathrm{g}$ of wild-type p53 expression plasmid, pC53-SN3; 5 $\mu \mathrm{g}$ pCMV-Z and $1 \mu \mathrm{g}$ of $\mathrm{p} 53$ plasmid (pC53-SCX3) mutated at amino acid 143; $5 \mu \mathrm{g}$ of the $\mathrm{R}$ expression vector, $\mathrm{pEBV}-\mathrm{RIE}$, which contains the EBV R transactivator protein in the pHD1013 vector; $5 \mu \mathrm{g}$ of the pEBV-RIE vector and $1 \mu \mathrm{g}$ of wild-type 553 plasmid. (D) The level of transfected $\mathrm{Z}$ protein (driven by the CMV IE promoter) was determined by Western blot analysis. D98/HE-R-1 cells were transfected with either the BHRF1-CAT plasmid and $\mathrm{pHD} 1013$ vector DNA (lane 1), BHRF1-CAT and pCMV-Z (lane 2), BHRF1-CAT and pCMV-Z plus wild-type p53 plasmid (lane 3), or BHRF1-CAT and pCMV-Z plus mutant p53 (lane 4). Z-induced transactivation of the early BHRF1 promoter in the same extracts (determined by CAT assay) was inhibited $80 \%$ by the presence of transfected wild-type (but not mutant) $\mathrm{p} 53$ protein (data not shown). Cotransfection of p53 protein did not significantly reduce the expression of transfected $Z$ protein. 

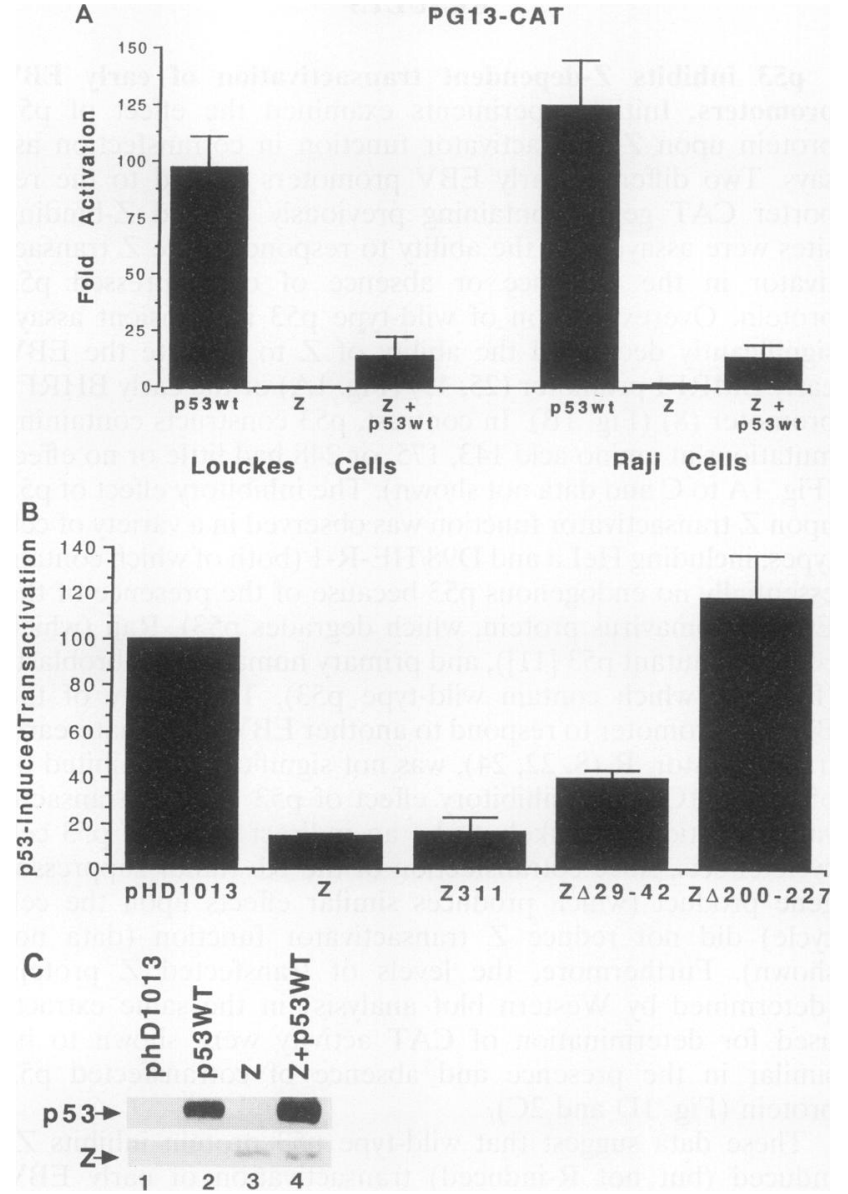

FIG. 2. $\mathrm{Z}$ inhibits p53-dependent transactivation. (A) Five micrograms of the pG13-CAT construct, which contains 13 copies of the p53-binding motif inserted upstream of the polyomavirus early promoter, was transfected into either Louckes cells (an EBV-negative Burkitt's lymphoma with mutant p53 [11]) or Raji cells (an EBVpositive Burkitt's lymphoma with mutant p53 [11]) with $1 \mu \mathrm{g}$ of the p53 expression plasmid and $5 \mu \mathrm{g}$ of the pHD1013 vector (p53wt), with $5 \mu \mathrm{g}$ of the $\mathrm{Z}$ expression plasmid (Z), or with $1 \mu \mathrm{g}$ of the p53 expression plasmid and $5 \mu \mathrm{g}$ of the $Z$ expression vector $(Z+p 53 w t)$. Results are expressed as fold activation of the pG13-CAT construct relative to vector DNA alone. The level of p53-dependent transactivation was decreased in the presence of the $Z$ gene product. (B) The ability of a series of $\mathrm{Z}$ mutants to inhibit p53-dependent transactivation was assessed in Raji cells. Columns (left to right): $5 \mu \mathrm{g}$ of the pG13-CAT plasmid with $1 \mu \mathrm{g}$ of the p53 expression construct and $5 \mu \mathrm{g}$ of pHD1013 vector DNA; $1 \mu \mathrm{g}$ of p53 plasmid and $5 \mu \mathrm{g}$ of pCMV-Z DNA; $1 \mu \mathrm{g}$ of the p53 expression plasmid and $5 \mu \mathrm{g}$ of the Z311 plasmid; $1 \mu \mathrm{g}$ of the p53 plasmid and $5 \mu \mathrm{g}$ of $\mathrm{Z} \Delta 29-42 ; 1 \mu \mathrm{g}$ of the p53 plasmid and $5 \mu \mathrm{g}$ of $\mathrm{Z} \Delta 200-227$. The mutant $\mathrm{Z}$ plasmids were constructed as previously described (30) except that they have been inserted into the pHD1013 vector. The Z311 construct contains a point mutation in the basic domain which inhibits DNA binding, the $\mathrm{Z} \Delta 29-42$ plasmid is deleted of amino acids 29 to 42 within the $\mathrm{Z}$ transactivator domain, and the $\mathrm{Z} \Delta \mathbf{2 0 0 - 2 2 7}$ plasmid is deleted of amino acids 200 to 227 in the coiled-coil dimerization domain (30). The results are expressed as the percent of p53-induced transactivation relative to the effect of $\mathrm{p} 53$ plus vector DNA, which produced an average 140 -fold activation in this set of experiments. (C) The level of transfected $\mathrm{p} 53$ protein in the presence and absence of cotransfected $\mathrm{Z}$ was assessed by Western blot analysis in the IMR-90 cell line (which contains endogenous wild-type p53). Lanes: $1,5 \mu \mathrm{g}$ of pHD1013 vector; $2,1 \mu \mathrm{g}$ of wild-type $\mathrm{p} 53$ plasmid and $5 \mu \mathrm{g}$ of pHD1013 vector; $3,5 \mu \mathrm{g}$ of $\mathrm{Z}$ expression plasmid; 4, $1 \mu \mathrm{g}$ of wild-type p53 and $5 \mu \mathrm{g}$ of $\mathrm{Z}$ expression plasmid. Expression of transfected p53 was assessed by variety of promoters (20), perhaps by inhibition of the TATAbinding protein (TBP) (56). However, our finding that $\mathrm{Z}$ dependent transactivation is much more sensitive to inhibition by $\mathrm{p} 53$ than $\mathrm{R}$-dependent transactivation suggested that p53 inhibition of $Z$ function might be due to a specific interaction between $Z$ and $p 53$.

$\mathrm{Z}$ inhibits p53-dependent transactivation. The $\mathrm{p} 53$ protein is a sequence-specific DNA-binding protein and transcriptional transactivator $(10,16,27,31,32,51,57)$. Recently, two viral proteins known to interact directly with p53 (the papillomavirus $\mathrm{E} 6$ protein and the adenovirus $\mathrm{E} 1 \mathrm{~b}$ protein) have been shown to inhibit p53-mediated effects in cotransfection assays $(36,72)$. If the $\mathrm{Z}$ and $\mathrm{p} 53$ proteins can also interact directly in vivo, then cotransfection of $Z$ with p53 might likewise be expected to inhibit p53-dependent transactivation. As shown in Fig. 2, this is indeed the case. Cotransfection of the wild-type $\mathrm{Z}$ construct with the $\mathrm{p} 53$ vector significantly reduced $\mathrm{p} 53-$ dependent transactivation in either Louckes cells (an EBVnegative Burkitt's lymphoma line) or Raji cells (an EBVpositive Burkitt's lymphoma line) (Fig. 2A). Both of these cell lines contain mutant p53 (11). Similar results were obtained in the primary human fibroblast cell line IMR-90, containing wild-type p53 (data not shown). Furthermore, the level of transfected p53 protein was assessed by Western blot analysis in IMR-90 cells and shown to be somewhat increased after cotransfection with $\mathrm{Z}$ (Fig. $2 \mathrm{C}$ ). Therefore, inhibition of $\mathrm{p} 53$ transactivator function by $\mathrm{Z}$ cannot be due to decreased expression of $\mathrm{p} 53$.

Inhibition of $\mathrm{p} 53$ transactivation was also observed with use of mutant $Z$ constructs in which either the DNA-binding function of $\mathrm{Z}$ had been abolished (plasmid Z311, containing a point mutation in the basic DNA-binding domain [30]) or the transactivator function had been inhibited (plasmid $Z \Delta 29-42$ [30]) (Fig. 2B). The Z $\Delta 200-227$ construct, in which the coiledcoiled dimerization domain of $\mathbf{Z}$ had been deleted, no longer inhibited p53 function. However, since this last mutant (in contrast to the other two mutants) does not produce stable nuclear $\mathrm{Z}$ protein (30), the failure of this mutant to inhibit $\mathrm{p} 53$ function is not necessarily due to the loss of the dimerization domain.

p53 inhibits disruption of EBV latency. To study the p53-Z interaction in a more biologically relevant context, we next examined the effect of p53 overexpression in EBV-infected cells. Transfection of $\mathrm{Z}$ into latently infected cells is sufficient to induce disruption of viral latency $(6,52,62)$. Lytically infected cells contain the productive, linear form of EBV as well as the episomal form (33). Restriction cutting with the enzyme Bam HI causes the linear form of the virus to appear as a ladder in gel electrophoresis as a result of the different number of terminal repeats present in each replicated virus (50). In latent EBV infection, the virus forms an episome (produced by fusion of the terminal repeats), and only one size restriction fragment is observed (50).

The Z-induced switch from latent to lytic EBV infection was examined by Southern blot and Western blot analysis (Fig. 3). As expected, with the induction of lytic viral replication, an increase in both the fused-termini form of virus (representing the formation of newly replicated head-to-tail concatemers which have not yet been cleaved) and the ladder form (representing the cleaved linear form of the virus) was observed (Fig.

Western blotting with monoclonal antibody DO-1 (top), and expression of transfected $\mathrm{Z}$ was quantitated by using monoclonal antibody BZ.1 (bottom). 


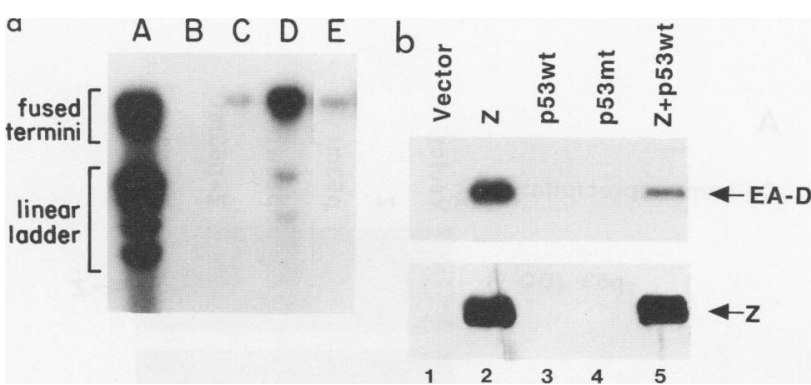

FIG. 3. The disruption of viral latency by $Z$ is inhibited by $p 53$ overexpression. (a) Latently infected D98/HE-R-1 cells were transfected with $5 \mu \mathrm{g}$ of pHD1013 vector DNA (lane C), $5 \mu \mathrm{g}$ of pCMV-Z plasmid DNA (lane D), or $5 \mu \mathrm{g}$ of pCMV-Z plus $10 \mu \mathrm{g}$ of wild-type p53 DNA (lane E). Lane A contains DNA from B95-8 cells (TPAsodium butyrate induced) to serve as the positive control for lytic EBV infection, and lane B contains DNA from the EBV-negative B-cell line Louckes. Cellular DNA was analyzed 3 days after transfection by cutting with the enzyme Bam HI and probing with a ${ }^{32} \mathrm{P}$-labeled riboprobe spanning the EBV sequences in the 1.9-kb XhoI fragment. As previously described (50), this probe can be used to determine the amount of EBV DNA containing unfused (linear) viral termini. The linear form of EBV is observed in productive (but not latent) EBV infection. The amounts of transfected plasmid DNA were determined by Southern blotting and shown to be equal in the presence and absence of cotransfected p53 (data not shown). The increase in the fused form of EBV observed during Z-induced lytic infection is due to the formation of head-to-tail concatemers which have not yet been cleaved. (b) The ability of transfected $\mathrm{Z}$ plasmid to disrupt viral latency in D98/HE-R-1 cells in the presence and absence of cotransfected p53 was analyzed by the Western blot procedure. Lanes: $1,5 \mu \mathrm{g}$ of pHD1013 vector DNA; 2, $5 \mu \mathrm{g}$ of $\mathrm{Z}$ expression plasmid; 3, $5 \mu \mathrm{g}$ of pHD1013 vector and $3 \mu \mathrm{g}$ of wild-type p53 plasmid; $4,5 \mu \mathrm{g}$ of pHD1013 vector and $3 \mu \mathrm{g}$ of mutant p53 plasmid; $5,5 \mu \mathrm{g}$ of $\mathrm{Z}$ expression vector and $3 \mu \mathrm{g}$ of wild-type p53 plasmid. Expression of the EA-D complex in the transfected cells was quantitated by using monoclonal antibody NEA-9240 (top), and expression of the Z protein was quantitated by using monoclonal antibody BZ.1 (bottom). The ability of transfected $\mathrm{Z}$ to induce expression of early protein was inhibited by cotransfection with wild-type p53, even though the level of transfected $\mathrm{Z}$ protein was not significantly reduced. Expression of mutant p53 alone is not sufficient to disrupt latency.

3a). The ability of transfected $\mathrm{Z}$ protein to disrupt viral latency in D98/HE-R-1 cells was diminished in the presence of cotransfected p53 protein. In contrast, overexpression of p53 in latently infected cells did not affect the level of episomal viral DNA. The amounts of transfected plasmid DNA (determined by Southern blot analysis) were also similar in the presence and absence of cotransfected p53 (data not shown).

Similarly, when the ability of transfected $\mathrm{Z}$ to induce expression of early EBV proteins was analyzed by Western blot analysis (Fig. 3b), the presence of cotransfected p53 significantly reduced the ability of $\mathrm{Z}$ to induce expression of the EBV early antigen-diffuse (EA-D) complex (BMRF1), although the levels of transfected $\mathrm{Z}$ protein were similar in the presence and absence of cotransfected p53. These results suggest that overexpression of wild-type p53 may promote viral latency by inhibiting the ability of $\mathbf{Z}$ to induce lytic replication.

$Z$ and $\mathbf{p 5 3}$ interact directly in vitro. To determine whether the $Z$ and $p 53$ proteins can interact directly in vitro, the ability of a Z-GST fusion protein to interact with in vitro-translated, ${ }^{35} \mathrm{~S}$-labeled p53 was investigated by affinity chromatography (Fig. 4). The intact 245-amino-acid Z protein (linked to GST) retained labeled p53 protein to glutathione-linked beads, whereas the beads alone or the beads coated with GST protein
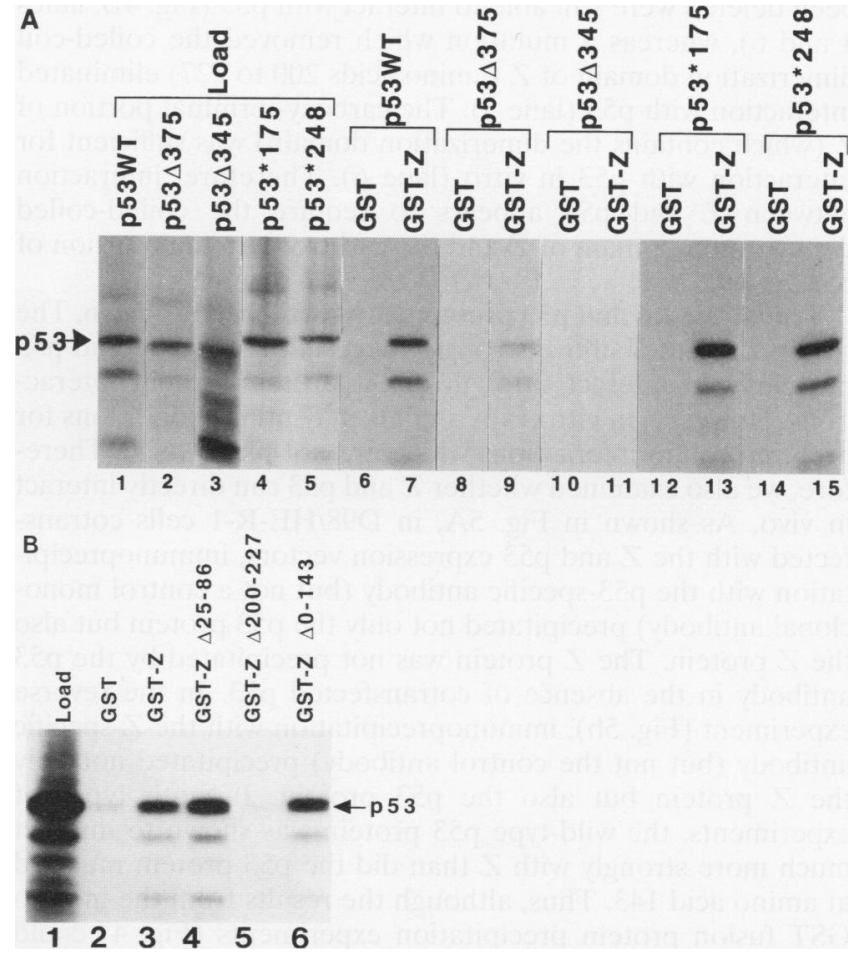

FIG. 4. A GST-Z fusion protein retains labeled p53 protein in affinity chromatography assays. The entire 245 -amino-acid $Z$ open reading frame was inserted into the pGEX-3X vector (Pharmacia) downstream of the GST protein to create the GST-Z fusion protein. Three deletions of GST-Z, removing either the transactivator domain ( $Z \Delta 25-86)$, the first 143 amino acids of $Z(Z \Delta 0-143)$, or the coiled-coil dimerization domain (Z $\Delta 200-227)$, were also constructed. The ability of these GST-Z fusion proteins to interact with ${ }^{35}$ S-labeled, in vitrotranslated p53 protein was evaluated in affinity chromatography studies using glutathione-linked beads. (A) Retention of the labeled wild-type $\mathrm{p} 53$ protein ( $553 \mathrm{WT})$ or mutant $\mathrm{p} 53$ proteins ( $533 \mathbf{3 7 5}$, $\mathrm{p} 53 \Delta 345$, p53*175, and p53*248) by the various GST columns is shown. The p53 $\Delta 375$ and p $53 \Delta 345$ constructs are truncated at amino acids 375 (removing the last 18 amino acids of p53) and 345 (removing the last 48 amino acids), respectively, whereas the p53*175 and p53*248 constructs contain point mutations in the amino acids indicated. The size of full-length in vitro-translated p 53 is indicated by the arrow (the smaller bands represent degradation products). Lanes: 1 to 5 , input wild-type and mutant p53 proteins; 6 to 15 , retention of the wild-type versus mutant $\mathrm{p} 53$ proteins by the GST protein alone versus the intact GST-Z fusion protein. (B) Retention of the wild-type p53 protein by the GST protein alone (lane 2), the intact GST-Z protein (lane 3), or the GST-Z proteins deleted in the transactivator domain (lane 4), the coiled-coil dimerization domain (lane 5), or the aminoterminal half (lane 6).

did not retain p53 (Fig. 4A, lanes 6 and 7). Removal of the final 18 amino acids from the 393-amino-acid p53 protein (p53 375 ) significantly reduced the interaction between $\mathrm{Z}$ and p53 (lanes 8 and 9), and removal of the last 48 amino acids of p53 (p53 $\Delta 345)$ totally abolished the interaction (lanes 10 and 11). Three mutant forms of p53 commonly observed in human tumors (26) (containing point mutations in amino acids 143, 175, and 248) were still capable of interacting with the GST-Z protein in this assay (lanes 12 to 15 , and data not shown), even though none of these mutant forms of p53 could inhibit $Z$ transactivation in vivo (Fig. 1A and data not shown). Mutant forms of the GST-Z protein in which the transactivator domain of $Z$ (which is required for interaction of $Z$ with TBP [40]) had 
been deleted were still able to interact with p53 (Fig. 4B, lanes 4 and 6), whereas a mutation which removed the coiled-coil dimerization domain of $Z$ (amino acids 200 to 227) eliminated interaction with p53 (lane 5). The carboxy-terminal portion of $\mathrm{Z}$ (which contains the dimerization domain) was sufficient for interaction with p53 in vitro (lane 6). Therefore, interaction between $\mathrm{Z}$ and p53 appears to require the coiled-coiled dimerization domain of $\mathbf{Z}$ and the carboxy-terminal portion of p53.

Transfected $Z$ and $p 53$ proteins interact directly in vivo. The results presented above strongly suggested that the $\mathrm{Z}$ and $\mathrm{p} 53$ proteins can interact through direct protein-protein interactions. However, in vitro experiments may utilize conditions for protein-protein interactions which are not physiologic. Therefore, we also examined whether $\mathrm{Z}$ and p53 can directly interact in vivo. As shown in Fig. 5A, in D98/HE-R-1 cells cotransfected with the $Z$ and $p 53$ expression vectors, immunoprecipitation with the p53-specific antibody (but not a control monoclonal antibody) precipitated not only the $\mathrm{p} 53$ protein but also the $\mathrm{Z}$ protein. The $\mathrm{Z}$ protein was not precipitated by the $\mathrm{p} 53$ antibody in the absence of cotransfected p53. In the reverse experiment (Fig. 5b), immunoprecipitation with the Z-specific antibody (but not the control antibody) precipitated not only the $\mathrm{Z}$ protein but also the p53 protein. In both types of experiments, the wild-type $\mathrm{p} 53$ protein was shown to interact much more strongly with $\mathrm{Z}$ than did the p53 protein mutated at amino acid 143. Thus, although the results from the in vitro GST fusion protein precipitation experiments (Fig. 4) could not distinguish between the ability of $\mathrm{Z}$ to interact with wild-type versus mutant $\mathrm{p} 53, \mathrm{Z}$ clearly interacted more efficiently in vivo with the wild-type protein. The discrepancy in the results obtained by these two different methods suggests either that a cellular protein (not present in reticulocyte extracts) can stabilize the interaction between $\mathrm{Z}$ and wild-type (but not mutant) p53 in vivo or that the GST fusion protein method may allow for stabilization of the weaker proteinprotein interaction between $\mathrm{Z}$ and the mutant $\mathrm{p} 53$ proteins.

Interestingly, as shown in Fig. 5B, we repeatedly found that cotransfection of $\mathrm{Z}$ with the $\mathrm{p} 53$ expression plasmids into D98/H-R-1 cells dramatically increased the level of transfected wild-type p53 protein and, to a much lesser extent, also increased the level of p53 mutated at amino acid 143. The ability of cotransfected $Z$ to increase the level of wild-type p53 protein to a greater extent than mutant p53 in D98/HE-R1 cells suggests that the interaction between $Z$ and p53 may prevent the p53 degradation induced by the papillomavirus E6 protein in this cell line (a fusion between HeLa and P3HR1 cells).

Expression of wild-type p53 in Akata cells inhibits anti-IgGinduced disruption of viral latency. To further confirm that expression of wild-type p53 inhibits disruption of viral latency, we examined the effect of anti-IgG treatment in Akata cell subclones (66) which have been stably transfected with either an inducible p53 expression vector (under the control of the metallothionein promoter) or the same vector without p53. The Burkitt's lymphoma Akata line, which normally produces no 553 protein (66), contains EBV in a tightly latent state but can be efficiently induced into lytic infection by treatment with anti-IgG (58). Anti-IgG treatment in Akata cells activates transcription of the BZLF1 promoter (58), and Z subsequently activates expression of the early EBV promoters.

As shown in Fig. 6A, Akata cells stably transfected with p53 under the control of the metallothionein promoter constitutively express a small amount of p53, which is vastly increased after cadmium chloride treatment. Akata cells stably transfected with the vector alone, as expected, express no p53.

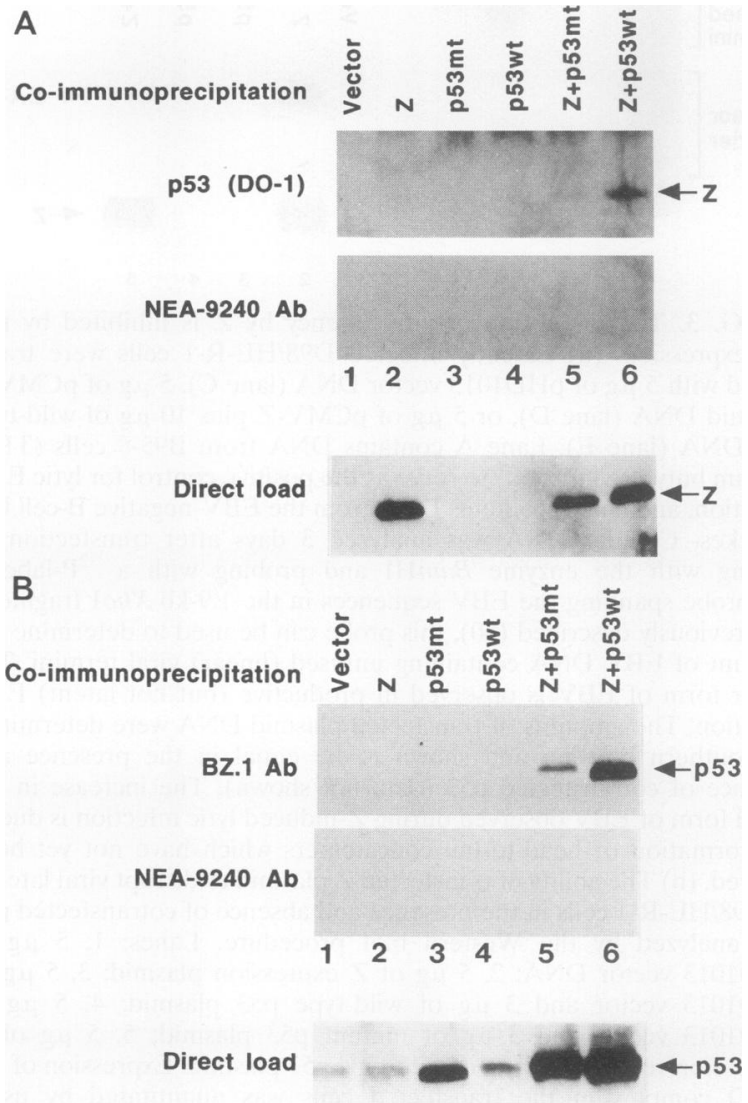

FIG. 5. Cotransfected $\mathrm{Z}$ and $\mathrm{p} 53$ can be coimmunoprecipitated in vivo. D98/HE-R-1 cells were transfected with either the pHD1013 vector (lane 1), the $Z$ expression plasmid pCMV-Z (lane 2), the p53 expression plasmid mutated at amino acid 143, pC53-SCX3 (lane 3), the wild-type p53 expression plasmid pC53-SN3 (lane 4), the $\mathrm{Z}$ and mutant p53 expression plasmids together (lane 5), or the $\mathrm{Z}$ and wild-type p53 expression plasmids together (lane 6). Whole cell extracts were harvested 2 days after transfection, and equal amounts of protein from each condition were incubated with an antibody $(\mathrm{Ab})$ directed against either the $\mathrm{Z}$ protein (BZ.1), the p53 protein (DO-1), or the EBV early BMRF1 protein (9240). Extracts were then immunoprecipitated with protein A-Sepharose 4B beads, separated by SDS-polyacrylamide gel electrophoresis, transferred to a nitrocellulose filter, and analyzed by Western blotting with antibody BZ.1 (A) or DO-1 (B) for the presence of $\mathrm{Z}$ and $\mathrm{p} 53$ proteins. (A) The amounts of $\mathrm{Z}$ protein in extracts immunoprecipitated with either the p53-specific antibody (top) or the BMRF1-specific control antibody (middle) were compared in the presence and absence of cotransfected p53 protein. The bottom panel shows the protein directly loaded onto the gel. Z protein was coimmunoprecipitated with the p53 antibody (but not the control antibody) in the presence of cotransfected p53 protein. Wildtype $\mathrm{p} 53$ coimmunoprecipitated the $\mathrm{Z}$ protein more efficiently than did mutant $\mathrm{p} 53$ protein in two separate experiments. (B) The amounts of p53 protein in extracts immunoprecipitated with either the Z-specific antibody (top) or the control antibody (middle) were compared in the presence and absence of cotransfected $\mathrm{Z}$ protein. The bottom panel shows protein directly loaded onto the gel. Wild-type $\mathrm{p} 53$ protein was coimmunoprecipitated with $\mathrm{Z}$ protein more efficiently than mutant $\mathrm{p} 53$ in two separate experiments. Cotransfection of $Z$ in the D98/HE-R-1 cell line consistently increased expression of transfected wild-type p53 to a greater extent than mutant p53. 


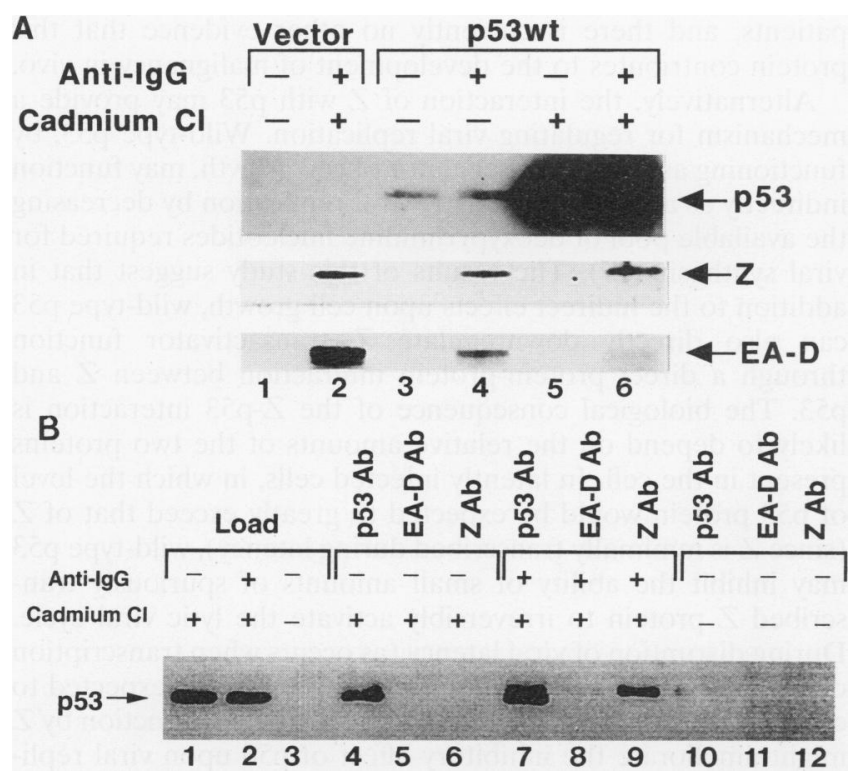

FIG. 6. Induction of p53 expression in stably transfected Akata cells inhibits anti-IgG-mediated disruption of viral latency. (A) The disruption of EBV latency in Akata cells stably transfected with either the pMEP4 vector (containing the inducible metallothionein promoter; Invitrogen) alone (lanes 1 and 2) or the p53 wild-type cDNA in the pMEP4 vector (lanes 3 to 6 ) was compared by Western blot analysis in the presence and absence of anti-IgG treatment (to induce $\mathrm{Z}$ expression) or the presence and absence of cadmium chloride (to induce p53 expression). The Akata Burkitt's lymphoma line normally contains no $\mathrm{p} 53$ (since both alleles are mutated [66]). Protein extracts were harvested after $12 \mathrm{~h}$ of anti-IgG treatment and $8 \mathrm{~h}$ of cadmium chloride treatment (begun $4 \mathrm{~h}$ after anti-IgG treatment). Expression of p53 was quantitated by using antibody DO-1 (top), expression of $Z$ was quantitated by using antibody BZ.1 (middle), and expression of the EA-D complex was quantitated by using antibody 9240 (bottom). The p53-transfected cell line expresses small amounts of p53 protein constitutively and much greater amounts of p53 after cadmium chloride treatment. The level of $\mathrm{Z}$ expression induced by anti-IgG treatment was not affected by the presence or absence of p53. However, the induction of early protein expression was inhibited by p53. (B) Coimmunoprecipitation experiments were performed to confirm that $\mathrm{Z}$ and p53 interact in vivo in the Akata cell line stably transfected with the inducible p53 expression vector. Extracts from uninduced cells (lanes 3 and 10 to 12), cells induced to express both $Z$ and p53 with anti-IgG antibody and cadmium chloride treatment (lanes 2 and 7 to 9), or cells induced to express p53 alone (with cadmium chloride treatment) (lanes 1 and 4 to 6 ) were either directly loaded onto the gel (lanes 1 to 3 ) or immunoprecipitated with mouse monoclonal antibodies directed against p53 (DO-1), EA-D (9240), or Z (BZ.1). The amount of $\mathrm{p} 53$ protein immunoprecipitated with each antibody was determined by Western blot analysis using the DO-1 antibody. The $\mathrm{Z}$ antibody coimmunoprecipitated p 53 only when both $\mathrm{Z}$ and p 53 were present in the cellular extracts.

Anti-IgG treatment of the cells containing either vector DNA or the p53 expression vector (in the presence or absence of cadmium chloride induction) induced expression of equivalent amounts of $Z$ protein, indicating that the presence of $\mathrm{p} 53$ does not affect the ability of anti-IgG to activate $Z$ transcription. However, the ability of $Z$ to induce expression of the EA-D complex was significantly decreased even by the small amounts of constitutive $\mathrm{p} 53$ expression found in the uninduced p53 cell line and was further decreased by the induction of p53 expression after cadmium chloride treatment. Therefore, the presence or absence of wild-type p53 can significantly alter the ability of $Z$ to disrupt viral latency.
$\mathrm{Z}$ and p53 also interact directly in Burkitt's lymphoma cells stably transfected with the inducible p53 expression vector. To confirm the importance of the in vivo interaction between $Z$ and p53, we ideally would demonstrate that the two proteins can be coimmunoprecipitated from nontransfected cells. However, since the experiments in transfected cells indicate that $\mathbf{Z}$ interacts efficiently in vivo only with wild-type (not mutant) $\mathrm{p} 53$, the ability to coimmunoprecipitate $\mathrm{Z}$ and p53 in nontransfected cells requires a cell line expressing reasonable levels of both $\mathrm{Z}$ and wild-type p53. After screening a variety of EBVpositive cell lines, we were unable to find any naturally occurring lines expressing high levels of both wild-type p53 and $\mathrm{Z}$. We therefore performed coimmunoprecipitation experiments in the stably transfected Akata subclones described above to determine whether an in vivo interaction between $\mathrm{Z}$ and p53 could be demonstrated in this cell line. The Akata cell lines were induced with either anti-IgG antibody as previously described (58) for $12 \mathrm{~h}$, cadmium chloride (at $5 \mu \mathrm{M}$, added 4 $h$ after the start of anti-IgG treatment), or both anti-IgG and cadmium chloride. As shown in Fig. 6B, in the cells induced with cadmium chloride and anti-IgG to express both p53 and Z, immunoprecipitation with a Z-specific antibody coimmunoprecipitated the $\mathrm{p} 53$ protein. In cells induced with cadmium chloride alone, the $\mathrm{Z}$ antibody did not coimmunoprecipitate p53, showing that $Z$ and p53 must both be present in the extract for coimmunoprecipitation to occur. These results indicate that $Z$ and p53 can interact directly in vivo in cells which have been stably transfected with an inducible p53 expression vector.

\section{DISCUSSION}

In this report, we have shown that an immediate-early EBV protein which plays an essential role in the switch from latent to lytic infection can interact directly with p53. The interaction between $Z$ and p53 in vitro appears to require the carboxyterminal portion of $\mathrm{p} 53$ and the dimerization domain of $\mathrm{Z}$. In vivo, the $Z$-p53 interaction results in inhibition of both the $Z$ and p53 transactivator functions. Our results suggest that one of the cellular determinants promoting EBV latency may be expression of the wild-type p53 tumor suppressor protein.

In EBV-infected B cells, the maintenance of viral latency is of paramount importance to cell survival, since Z-mediated activation of early EBV promoters is likely to lead to lysis and death of the host cell. The regulation of viral latency in B cells occurs through at least two different mechanisms. One level of regulation involves the transcriptional control of the two promoters driving $\mathrm{Z}$ gene expression (43). Both of these promoters are normally silent in B cells $(29,74)$ but can be activated by tetradecanoyl phorbol acetate (TPA) (15), antiIgG (58), or the $Z$ protein itself $(14,64)$. However, since the $Z$ gene product can positively regulate its own transcription, even small amounts of spurious $Z$ gene transcription might be expected to irreversibly activate the lytic cycle if there were not additional negative control mechanisms. In keeping with this notion, we have recently shown that the efficiency of $Z$ transactivator function (even when driven by a heterologus promoter which functions well in all cell types) is very cell type specific $(25,49)$. These data suggest that in addition to the transcriptional regulation of the $\mathrm{Z}$ promoters, the efficiency of $\mathrm{Z}$ transactivator function itself can also be regulated in a cell-type-specific fashion.

Recently, we and others have found that $\mathrm{Z}$ interacts with a number of viral and cellular proteins. In addition to interacting with $\mathrm{p} 53, \mathrm{Z}$ can also interact directly with retinoic acid receptors (59), the p65 component of NF-кB (23), TBP (40), 
and several viral proteins $(17,28)$. The interaction of $\mathrm{Z}$ with the p65 protein or the retinoic acid receptors results in decreased $Z$ function $(23,59)$. In contrast, we have shown that the $c-m y b$ gene product can activate $\mathrm{Z}$ transactivator function (30), apparently through an indirect mechanism. We have not totally excluded the possibility that the interaction between $\mathrm{Z}$ and p53 is mediated through one of these other proteins, since each of the assays used to examine protein-protein interactions included either reticulocyte lysate or cellular extracts. However, it is unlikely that interaction between $\mathrm{Z}$ and p53 is mediated through TBP, since TBP interacts with the transactivator domain of $Z(40)$, whereas this region is dispensable for the interaction between $\mathrm{Z}$ and $\mathrm{p} 53$.

Although the wild-type p53 protein inhibits the activity of numerous different cellular and viral promoters (20), the mechanism of p53 inhibition has not been well defined. Recently, p53 has been shown to directly interact with several cellular proteins, including TBP (56), a CCAAT box-binding protein (1), Wt1 (42), and Sp1 (4). The inhibition of TBP function may explain the ability of $\mathrm{p} 53$ to downregulate numerous different promoters. Our finding that the interaction of $\mathrm{p} 53$ with $\mathrm{Z}$ is mediated through the coiled-coil dimerization domain of $Z$ suggests yet another mechanism by which p53 could potentially downregulate the activity of promoters, since numerous cellular transcription factors (including c-Fos and c-Jun) contain similar dimerization domains.

Although the carboxy-terminal portion of p53 is rarely involved in spontaneous tumor mutations (26), this domain of p53 has now been shown to be required for interaction with TBP, the hsc-70 protein, and Z (48). In addition, the carboxyterminal portion of the protein, which contains two phosphorylation sites, is required for oligomerization of p53, DNA binding, and transformation of cells $(48,65)$. The $\mathrm{Z}$ protein, by directly interacting with this critical domain of $\mathrm{p} 53$, could potentially affect any of these p53 functions.

What is the biologic significance of the Z-p53 interaction? Our finding that the $\mathrm{Z}$ protein can inhibit $\mathrm{p} 53$-dependent transactivation suggests that overexpression of $\mathrm{Z}$ in EBVpositive tumors could potentially play a role in tumor formation. However, the $\mathrm{Z}$ protein is generally not expressed in EBV-positive Burkitt's lymphomas in vivo or in latently infected (but immortalized) B-cell lines in vitro $(33,44)$. Therefore, it is difficult to envision that inactivation of $p 53$ function by $\mathrm{Z}$ contributes to EBV-associated transformation in Burkitt's lymphoma or is required for immortalization of primary $B$ cells.

In contrast, immunocompromised patients (in particular organ transplant recipients and patients with AIDS) have a high frequency of EBV-associated lymphomas, and in these patients, up to $60 \%$ of EBV-positive lymphomas contain cells expressing the $\mathrm{Z}$ protein (46). $\mathrm{Z}$ is also expressed in a small percentage of nasopharyngeal carcinoma cells (7) and in Reed-Sternberg cells of EBV-positive Hodgkin's disease (47). The abortive expression of viral early antigens during impaired cellular immunity could potentially provide a setting in which the inhibition of $\mathrm{p} 53$ function by $\mathrm{Z}$ can complement the transforming functions of the latent EBV gene products. Although EBV-positive Burkitt's lymphomas (which are latently infected in vivo and do not express $Z$ ) commonly contain mutated p53 $(11,18,71)$, other types of EBV-containing malignancies (including nasopharyngeal carcinomas and EBVassociated lymphomas in immunocompromised hosts) generally contain wild-type p53 $(9,49 a)$. Nevertheless, the expression of $\mathrm{Z}$ protein in lymphomas and nasopharyngeal carcinoma may simply reflect the immunocompromised state of these patients, and there is currently no other evidence that this protein contributes to the development of malignancy in vivo.

Alternatively, the interaction of $\mathrm{Z}$ with $\mathrm{p} 53$ may provide a mechanism for regulating viral replication. Wild-type $\mathrm{p} 53$, by functioning as a negative regulator of cell growth, may function indirectly as an inhibitor of lytic viral replication by decreasing the available pool of deoxypyrimidine nucleotides required for viral synthesis (37). The results of this study suggest that in addition to the indirect effects upon cell growth, wild-type p53 can also directly downregulate $\mathrm{Z}$ transactivator function through a direct protein-protein interaction between $\mathrm{Z}$ and p53. The biological consequence of the $Z$-p53 interaction is likely to depend on the relative amounts of the two proteins present in the cell. In latently infected cells, in which the level of $\mathrm{p} 53$ protein would be expected to greatly exceed that of $\mathrm{Z}$ (since $\mathrm{Z}$ is minimally transcribed during latency), wild-type p53 may inhibit the ability of small amounts of spuriously transcribed $\mathrm{Z}$ protein to irreversibly activate the lytic viral cycle. During disruption of viral latency (as occurs when transcription of $\mathbf{Z}$ is activated), the level of $\mathbf{Z}$ protein would be expected to exceed that of p53. In this case, inhibition of p53 function by $Z$ might ameliorate the inhibitory effect of p53 upon viral replication.

$\mathrm{Z}$ may not be the only EBV-encoded protein which interacts directly with p53. Another group has recently reported that the EBV leader protein, which is expressed during latent viral infection, can also be coimmunoprecipitated with the p53 tumor suppressor protein (61). As yet, no data have been published regarding the possible functional consequences of this interaction, and it is unknown whether the EBV leader protein, like $\mathrm{Z}$, can inhibit $\mathrm{p} 53$-dependent transactivation. The necessity for two different virally encoded proteins which interact with p53 may reflect the fact that EBV uses separate origins of replication during latent versus productive infection. It is possible that the interaction between the leader protein and p53 mediates viral replication during latent infection (through the ori-P origin), whereas the interaction between $\mathrm{Z}$ and p53 modulates replication during productive infection (through the ori-Lyt origin).

It has been hypothesized that the interaction of papillomavirus, simian virus 40 , and adenovirus with p53 serves to promote cell growth and thereby enhance viral replication (37). That EBV also encodes proteins targeting p53 suggests that inactivation of $\mathrm{p} 53$ function may be a common requirement for the replication of many types of DNA viruses. We have demonstrated that $\mathrm{Z}$ and p53 interact in vitro and in vivo and that this interaction may inhibit the ability of $\mathrm{Z}$ to disrupt viral latency. We are currently pursuing further experiments to determine whether p53 status does indeed influence the stringency of EBV latency.

\section{ACKNOWLEDGMENTS}

We thank Joseph Pagano, Nancy Raab-Traub, Al Baldwin, Thea Tlsty, and Buddy Weissman for critical reading of the manuscript. We thank Bert Vogelstein and Scott Kern for p53 expression and reporter plasmids, Alain Sergeant for the Z cDNA and Z mutants, and Alan Rickinson for the $\mathbf{Z}$ monoclonal antibody. We thank Steve Oglesbee for help growing the stably transfected Akata cell lines and Judy Hall for preparing the manuscript.

This work was supported by grants P01-CA19014 and K04-CA01711 from the National Institutes of Health and MV-532 from the American Cancer Society.

\section{REFERENCES}

1. Agoff, S. N., J. Hou, D. Linzer, and B. Wu. 1993. Regulation of the human hsp70 promoter by p53. Science 259:84-87. 
2. Baker, S., S. Markowitz, E. Fearon, J. Willson, and B. Vogelstein. 1990. Suppression of human colorectal carcinoma cell growth by wild-type p53. Science 249:912-915.

3. Bargonetti, J., P. Friedman, S. Kern, B. Vogelstein, and C. Prives. 1991. Wild-type but not mutant p53 immunopurified proteins bind to sequences adjacent to the SV40 origin of replication. Cell 65:1083-1091.

4. Borellini, F., and R. Glazer. 1993. Induction of Sp1-p53 DNAbinding heterocomplexes during granulocyte/macrophage colonystimulating factor-dependent proliferation in human erythroleukemia cell line TF-1. J. Biol. Chem. 268:7923-7928.

5. Chang, Y., D. Dong, G. Hayward, and S. D. Hayward. 1990. The Epstein-Barr virus Zta transactivator: a member of the bZIP family with unique DNA-binding specificity and a dimerization domain that lacks the characteristic heptad leucine zipper motif. J. Virol. 64:3358-3369.

6. Chevallier-Greco, A., E. Manet, P. Chavrier, C. Mosnier, J. Daillie, and A. Sergeant. 1986. Both Epstein-Barr virus (EBV) encoded trans-acting factors, EB1 and EB2, are required to activate transcription from an early EBV promoter. EMBO $\mathbf{J}$. 5:3243-3249.

7. Cochet, C., D. Martel-Renoir, V. Grunewald, J. Bosq, G. Cochet, G. Schwaab, J.-F. Bernaudin, and I. Joab. 1993. Expression of the Epstein-Barr virus immediate-early gene, BZLF1, in nasopharyngeal carcinoma tumor cells. Virology 197:358-365.

8. Cox, M., J. Leahy, and J. M. Hardwick. 1990. An enhancer within the divergent promoter of Epstein-Barr virus responds synergistically to the $\mathrm{R}$ and $\mathrm{Z}$ transactivators. J. Virol. 64:313-321.

9. Effert, P., R. McCoy, M. Abdel-Hamid, K. Flynn, Q. Zhang, P. Busson, T. Tursz, E. Liu, and N. Raab-Traub. 1992. Alterations of the p53 gene in nasopharyngeal carcinoma. J. Virol. 66:3768-3775.

10. Farmer, G., J. Bargonetti, H. Zhu, P. Friedman, R. Prywes, and C. Prives. 1992. Wild-type p53 activates transcription in vitro. Nature (London) 358:83-86.

11. Farrell, P., G. Allen, F. Shanahan, K. Vousden, and T. Crook. 1991. p53 is frequently mutated in Burkitt's lymphoma cell lines. EMBO J. 10:2879-2887.

12. Farrell, P., D. Rowe, C. Rooney, and T. Kouzarides. 1989. EpsteinBarr virus BZLF1 trans-activator specifically binds to consensus Ap1 site and is related to c-fos. EMBO J. 8:127-132.

13. Fixman, E., G. Hayward, and S. D. Hayward. 1992. trans-acting requirements for replication of Epstein-Barr virus ori-Lyt. J. Virol. 66:5030-5039.

14. Flemington, E., and S. Speck. 1990. Autoregulation of EpsteinBarr virus putative lytic switch gene BZLF1. J. Virol. 64:12271232.

15. Flemington, E., and S. Speck. 1990. Identification of phorbol ester response elements in the promoter of Epstein-Barr virus putative lytic switch gene BZLF1. J. Virol. 64:1217-1216.

16. Funk, W., D. Pak, R. Karas, W. Wright, and J. Shay. 1992. A transcriptionally active DNA-binding site for human p53 protein complexes. Mol. Cell. Biol. 12:2866-2871.

17. Furnari, F. B., V. Zacny, E. B. Quinlivan, S. Kenney, and J. S. Pagano. 1994. RAZ, an Epstein-Barr virus transdominant repressor that modulates the viral reactivation mechanism. J. Virol. 68:1827-1836.

18. Gaidano, G., P. Ballerini, J. Gong, G. Inghirami, A. Neri, E. Newcomb, I. Magrath, D. Knowles, and R. Dalla-Favera. 1991. p53 mutations in human lymphoid malignancies: association with Burkitt lymphoma and chronic lymphocytic leukemia. Proc. Natl. Acad. Sci. USA 88:5413-5417.

19. Gannon, J., and D. Lane. 1987. p53 and DNA polymerase a compete for binding to SV40 T antigen. Nature (London) 329: 456-458.

20. Ginsberg, D., F. Mechta, M. Yaniv, and M. Oren. 1991. Wild-type p53 can down-modulate the activity of various promoters. Proc. Natl. Acad. Sci. USA 88:9979-9983.

21. Gorman, C. M., L. F. Moffat, and B. H. Howard. 1982. Recombinant genomes which express chloramphenicol acetyltransferase in mammalian cells. Mol. Cell. Biol. 2:1044-1051.

22. Gruffat, H., E. Manet, A. Rigolet, and A. Sergeant. 1990. The enhancer factor $R$ of Epstein-Barr virus (EBV) is a sequence specific DNA binding protein. Nucleic Acids Res. 18:6835-6843.
23. Gutsch, D. E., E. A. Holley-Guthrie, Q. Zhang, B. Stein, M. A. Blanar, A. S. Baldwin, and S. C. Kenney. 1994. The bZIP transactivator of Epstein-Barr virus, BZLF1, functionally and physically interacts with the p65 subunit of NF-кB. Mol. Cell. Biol. 14:1939-1948.

24. Hardwick, J. M., S. Lazarowits, and S. D. Hayward. 1988. A new Epstein-Barr virus transactivator, $\mathrm{R}$, induces expression of a cytoplasmic early antigen. J. Virol. 62:2274-2284.

25. Holley-Guthrie, E., E. Quinlivan, E. Mar, and S. Kenney. 1990. The Epstein-Barr virus promoter for early antigen (EA-D) is regulated by the EBV transactivators, BRLF1 and BZLF1, in a cell-specific manner. J. Virol. 64:3753-3759.

26. Hollstein, M., D. Sidransky, B. Vogelstein, and C. Harris. 1991. p53 mutations in human cancers. Science 253:49-53.

27. Hupp, T., D. Meek, C. Midgley, and D. Lane. 1992. Regulation of the specific DNA binding function of p53. Cell 71:875-886.

28. Katz, D., R. Baumann, R. Sun, J. Kolman, N. Taylor, and G. Miller. 1992. Viral proteins associated with the Epstein-Barr virus transactivator, ZEBRA. Proc. Natl. Acad. Sci. USA 89:378-382.

29. Kenney, S., J. Kamine, E. Holley-Guthrie, J. Lin, E. Mar, and J. Pagano. 1989. The Epstein-Barr virus (EBV) BZLF1 immediateearly gene product differentially affects latent versus productive EBV promoters. J. Virol. 63:1729-1736.

30. Kenney, S., E. Holley-Guthrie, E. Quinlivan, D. Gutsch, T. Bender, J. Giot, and A. Sergeant. 1992. The cellular oncogene c-myb can interact synergistically with the Epstein-Barr virus BZLF1 transactivator in lymphoid cells. Mol. Cell. Biol. 12:136-146.

31. Kern, S., K. Kinzler, S. Baker, J. Nigro, V. Rotter, A. Levine, P. Friedman, C. Prives, and B. Vogelstein. 1991. Identification of p53 as a sequence-specific DNA-binding protein. Science 252:17081711.

32. Kern, S., J. Pietenpol, S. Thiagalingam, A. Seymour, K. Kinzler, and B. Vogelstein. 1992. Oncogenic forms of p53 inhibit p53regulated gene expression. Science 256:827-830.

33. Kieff, E., and D. Leibowitz. 1990. Epstein-Barr virus and its replication, p. 1889-1920. In B. Fields and D. Knipe (ed.), Fields virology, 2nd ed., Raven Press, New York.

34. Kouzarides, T., G. Packham, A. Cook, and P. Farrell. 1991. The BZLF1 protein of EBV has a coiled coil dimerization domain without a hepted leucine repeat but homology to the C/EBP leucine zipper. Oncogene 6:195-204.

35. Lane, D., and L. Crawford. 1979. T antigen is bound to a host protein in SV40-transformed cells. Nature (London) 278:261-263.

36. Lechner, M., D. Mack, A. Finicle, T. Crook, K. Vousden, and L. Laimins. 1992. Human papillomavirus E6 proteins bind p53 in vivo and abrogate p53-mediated repression of transcription. EMBO J. 11:3045-3052.

37. Levine, A. 1990. p53 protein and its interactions with the oncogene products of the small DNA tumor viruses. Virology 177:419-426.

38. Levine, A., J. Momand, and C. Finlay. 1991. The p53 tumor suppressor gene. Nature (London) 351:453-456.

39. Lieberman, P., and A. Berk. 1990. In vitro transcriptional activation, dimerization, and DNA-binding specificity of the EpsteinBarr virus Zta protein. J. Virol. 64:2560-2568.

40. Lieberman, P., and A. Berk. 1991. The Zta transactivator protein stabilizes TFIID association with promoter DNA by direct protein-protein interaction. Genes Dev. 5:2441-2454.

41. Luka, J., B. Kallin, and G. Klein. 1979. Induction of the EpsteinBarr virus cycle in latently infected cells by $n$-butyrate. Virology 94:228-231.

42. Maheswaran, S., S. Park, A. Bernard, J. Morris, F. Rauscher, D. Hill, and D. Haber. 1993. Physical and functional interaction between WT1 and p53 proteins. Proc. Natl. Acad. Sci. USA 90:5100-5104.

43. Manet, E., H. Gruffat, M. C. Trescol-Biemont, I. Moreno, P. Chambard, J. F. Giot, and A. Sergeant. 1989. Epstein-Barr virus bicistronic mRNA's generated by facultative splicing code for two transcriptional trans-activators. EMBO J. 8:1819-1826.

44. Miller, G. 1990. The Epstein-Barr virus, p. 1291-1957. In B. Fields, D. Knipe, et al. (ed.), Fields virology. Raven Press, New York.

45. Moar, M., R. Ber, G. Klein, A. Westman, and I. Eriksson. 1978. Somatic cell hybrids between human lymphoma cell lines. V. IdUrd inducibility and P3HR-1 superinfectability of DAUDI/ 
HeLa (DAD) and DAUDI/P3HR-1 (DIP-1) cell lines. Int. J. Cancer 22:669-674.

46. Pallesen, G., S. Hamilton-Dutoit, M. Rowe, I. Lisse, E. Ralfkiaer, K. Sandvej, and L. Young. 1990. Expression of Epstein-Barr virus replicative proteins in AIDS-related non-Hodgkin's lymphoma cells. J. Pathol. 165:289-299.

47. Pallesen, G., K. Sandvej, S. Hamilton-Dutoit, M. Rowe, and L. Young. 1991. Activation of Epstein-Barr virus replication in Hodgkin and Reed-Sternberg cells. Blood 78:1162-1165.

48. Prives, C., and J. Manfredi. 1993. The p53 tumor suppressor protein: meeting review. Genes Dev. 7:529-534.

49. Quinlivan, E., E. Holley-Guthrie, M. Norris, D. Gutsch, S. Bachenheimer, and S. Kenney. 1993. Direct BRLF1 binding is required for cooperative BZLF1/BRLF1 activation of the EpsteinBarr virus promoter, BMRF1. Nucleic Acids Res. 21:1999-2007.

49a.Raab-Traub, N. Personal communication.

50. Raab-Traub, N., and K. Flynn. 1986. The structure of the termini of the Epstein-Barr virus as a marker of clonal cellular proliferation. Cell 47:883-889.

51. Raycroft, L., H. Wu, and G. Lozano. 1990. Transcriptional activation by wild-type but not transforming mutants of the p53 antioncogene. Science 249:1049-1051.

52. Rooney, C., N. Taylor, J. Countryman, H. Jenson, J. Kolman, and G. Miller. 1988. Genome rearrangements activate the EpsteinBarr virus gene whose product disrupts latency. Proc. Natl. Acad. Sci. USA 85:9801-9805.

53. Sarnow, P., Y. Ho, J. Williams, and A. Levine. 1982. Adenovirus E1b-58 kd tumor antigen and SV40 large T antigen are physically associated with the same $54 \mathrm{kd}$ cellular protein in transformed cells. Cell 28:387-394.

54. Scheffner, M., B. Werness, J. Huibregtse, A. Levine, and P. Howley. 1990. The E6 oncoprotein encoded by human papillomavirus types 16 and 18 promotes the degradation of p53. Cell 63:1129-1136.

55. Schepers, A., D. Pich, and W. Hammerschmidt. 1993. A transcription factor with homology to the Ap1 family links RNA transcription and DNA replication in the lytic cycle of Epstein-Barr virus. EMBO J. 12:3921-3929.

56. Seto, E., A. Usheva, G. Zambetti, J. Momand, N. Horikoshi, R. Weinmann, A. Levine, and T. Shenk. 1992. Wild-type p53 binds to the TATA-binding protein and represses transcription. Proc. Natl. Acad. Sci. USA 89:12028-12032.

57. Shaulian, E., A. Zauberman, D. Ginsgerg, and M. Oren. 1992. Identification of a minimal transforming domain of p53: negative dominance through abrogation of sequence-specific DNA binding. Mol. Cell. Biol. 12:5581-5592.

58. Shimizu, N., and K. Takada. 1993. Analysis of the BZLF1 promoter of Epstein-Barr virus: identification of an anti-immunoglobulin response sequence. J. Virol. 67:3240-3245.

59. Sista, N., J. Pagano, W. Liao, and S. Kenney. 1993. Retinoic acid is a negative regulator of the Epstein-Barr virus protein (BZLF1) that mediates disruption of latent infection. Proc. Natl. Acad. Sci. USA 90:3894-3898.
60. Smith, D., and K. Johnson. 1987. Single-step purification of polypeptides expressed in Escherichia coli as fusions with glutathione S-transferase. Gene 67:31-40.

61. Szekely, L., G. Selivanova, K. Magnusson, G. Klein, and K. Wimon. 1993. EBNA-5, an Epstein-Barr virus-encoded nuclear antigen, binds to the retinoblastoma and p53 proteins. Proc. Natl. Acad. Sci. USA 90:5455-5459.

62. Takada, K., N. Shimuzu, S. Sakuma, and A. Keating. 1986. Transactivation of the latent Epstein-Barr virus (EBV) genome after transfection of the EBV BamHI Z DNA fragment. J. Virol. 57:1011-1022.

63. Ullrich, S., C. Anderson, W. E. Mercer, and E. Appella. 1992. The p53 tumor suppressor protein, a modulator of cell proliferation. $\mathbf{J}$. Biol. Chem. 267:15259-15262.

64. Urier, G., M. Buisson, P. Chambar, and A. Sergeant. 1989. The Epstein-Barr virus early protein EB1 activates transcription from different responsive elements including Ap1 binding sites. EMBO J. 8:1447-1453.

65. Vogelstein, B., and K. Kinzler. 1992. p53 function and dysfunction. Cell 70:523-526.

66. Vousden, K., T. Crook, and P. Farrell. 1993. Biological activities of p53 mutants in Burkitt's lymphoma cells. J. Gen. Virol. 74:803810 .

67. Wang, E., P. Friedman, and C. Prives. 1989. The murine p53 protein blocks replication of SV40 DNA in vitro by inhibiting the initiation functions of SV40 large T antigen. Cell 57:379-392.

68. Werness, B., A. Levine, and P. Howley. 1990. Association of human papillomavirus types 16 and $18 \mathrm{E} 6$ proteins with $\mathrm{p} 53$. Science 248:76-79.

69. Whyte, P., N. Williamson, and E. Harlow. 1989. Cellular targets for transformation by the adenovirus E1A proteins. Cell 56:67-75.

70. Wilcock, D., and D. Lane. 1991. Localization of p53, retinoblastoma and host replication proteins at sites of viral replication in herpes-infected cells. Nature (London) 349:429-431.

71. Wiman, K., K. Magnusson, T. Ramgvist, and G. Klein. 1991. Mutant p53 detected in a majority of Burkitt lymphoma cell lines by monoclonal antibody PAb240. Oncogene 6:1633-1639.

72. Yew, P., and A. Berk. 1992. Inhibition of p53 transactivation required for transformation by adenovirus early $1 \mathrm{~B}$ protein. Nature (London) 357:82-85.

73. Young, L., R. Lau, M. Rowe, G. Niedobitek, G. Packham, F. Shanahan, D. Rowe, D. Greenspan, J. Greenspan, A. Rickinson, and P. Farrell. 1991. Differentiation-associated expression of the Epstein-Barr virus BZLF1 transactivator in oral hairy leukoplakia. J. Virol. 65:2868-2874.

74. Zalani, S., E. Holley-Guthrie, D. Gutsch, and S. Kenney. 1992. The Epstein-Barr virus immediate-early promoter, BRLF1, can be activated by the cellular Sp1 transcription factor. J. Virol. 66:72827292.

75. Zur Hausen, H., G. Bornkamm, R. Schmidt, and E. Hecker. 1979. Tumor initiators and promoters in the induction of Epstein-Barr virus. Proc. Natl. Acad. Sci. USA 76:782-785. 